\title{
Western Organizational Theories: Middle Eastern Style: How much do you Know about the Culture?
}

\author{
Maurice Abi-Raad \\ Rabdan Academy, Abu Dhabi, United Arab Emirates \\ mabiraad@ra.ac.ae
}

Received date: 22 January 2018; Accepted date: 19 July 2018; Published date: 14 January 2019

Academic Editor: Norizan Mohd Kassim

Copyright (C) 2019. Maurice Abi-Raad . Distributed under Creative Commons CC-BY 4.0

\begin{abstract}
The strategic vision of minimizing oil dependence in the Middle East has triggered a flurry of innovations, investments, and management initiatives in many public and private organizations (Goyal and Rishi 2003). The Middle East has Western experts working diligently to bring Western theories and practices into the region, promising a better future with tangible improvements. While this can be considered a very noble cause, in many instances, it is assumed that the people who are at the center of all these theories ought to be Western-minded for these principles to work. Adopting Western management concepts in Middle Eastern organizations has always been a challenge for many experts, especially during the implementation phase. The Middle Eastern culture, organizational dynamics, value systems, as well as learning styles are just some of the challenges in the region. Preserving and understanding the local culture and adjusting organizational and management theories to fit the culture should be the way to go - not the other way around. As the first stage of the research, this paper presents a literature review to understand the challenges of adopting Western-style organizational theories and management, and elucidate how these need to be adapted to be culturally sensitive for the Middle East. It discusses the eligibility of Western-style organizational theories in the realities of the Middle East through a number of aspects. The findings of this paper form the basis of an interview instrument that will be used to gather the opinions of experienced Middle Eastern organizational leaders working with Western experts.
\end{abstract}

Keywords: Applied Western organizational theories; Doing business in the Middle East; Cultural Preservation.

Cite this Article as: Maurice Abi-Raad (2019)," Western Organizational Theories: Middle Eastern Style: How much do you Know about the Culture?" The Journal of Organizational Management Studies, Vol. 2019 (2019), Article ID 730213, DOI: 10.5171/2019.730213 


\section{Introduction}

Culture and management are highly interrelated, meaning that a distinction between management styles and associated cultural differences need to be considered (Mathebula 2017; Raduški 2016). This paper posits that local governments in the Middle East must create a favorable business environment for international investors, while foreign enterprises must also gain a comprehensive understanding of the Middle East's cultural characteristics and their effect on the management style adopted.

Numerous studies have been conducted to explore the applicability of Western management strategies in the Middle East (Ramdani et al 2014; Weir and Hutchings 2005). The purpose of this paper is to identify the challenges facing Western experts working on implementing/adapting management and organizational theories that have been proven to be successful in the West in the Middle East (Ramdani et al 2014).

This study is based on an analysis of the relevant available literature. Consequently, cultural and managerial characteristics of both; the West and the Middle East, their business opportunities, as well as barriers for implementing Western-style management practices in the Middle East have been identified.

The Middle East region covers a large territory of 18 states. Mostly rich in oil and gas, the local economy grew on being totally or mostly dependent on these natural resources (Oil \& Gas Industry Profile: Middle East 2014). Over the past decade, governments in the Middle East have decided to change direction by reducing oil and gas dependency, focusing on creating sustainable economies through service and business developments (Kovac 2007; Platt 2012; Saigal 2013). By creating a favorable business environment, the Middle Eastern states are better placed for investment. To run a successful business in the Middle East, business relationships must be the core priority (Musibah, Shahzad and Bt Fadzil 2015; Odell 2017; Middle East Monitor: Gulf 2014). However, the region has cultural and management characteristics that differentiate it from the rest of the world (Ramdani et al 2014).

\section{Research Methodology}

The author chose a literature review approach because it best served the initial stage of the project. Online database searches were conducted in various iterations to retrieve articles related to the experiences of Western experts working in the Middle East. A range of articles were reviewed to specifically identify key challenges related to the applicability of Western organizational theories in the Middle East.

\section{High- and Low-Context Cultures}

Weir and Hutchings (2005) state that business relationships in different cultures are "an important vehicle" for conducting business in "high-context" cultures, namely; the Middle Eastern states. Arab culture, being the dominant culture in the region, differs from Western culture, especially when it comes to communication principles (Weir and Hutchings 2005). Arab culture is defined as a high-context culture that supports an indirect style of communication, while Western culture is defined as a low-context culture that supports a direct style of communication. Weir and Hutchings (2005) were the first to explore the Arab management style as a separate type of behavior with its own characteristics.

However, Weir and Hutchings' (2005) vision has been highly criticized by Khdour, Harris, and Saif (2015); the authors of a multiple case study on the Telecoms Sector in Jordan. Khdour, Harris, and Saif (2015) suggest classifying Middle Eastern management into three groups: Westernized, Arabized, and Islamized. The main criteria considered by the researchers 
are the sociocultural effects of the Western world, the impact of Arab culture, and the role of Arab managers and their behavior (Khdour, Harris and Saif 2015).

An article in the Academy of Management Journal published by Barkema et al (2015) discusses the contextual challenges regarding the relationships between East and West. The rapid economic development of the Middle East and immense funding from Western countries to that region demands mutual agreement on many cultural, social, and business aspects. While establishing democracy at the state level may not be possible due to cultural differences, the implementation of democratic policies and regulations by local and foreign enterprises can lead to profitable cooperation (Barkema et al 2015).

Power distance measures the extent to which a person can accept unequal distribution of power in various institutions and organizations (Mone, Benga and Opre 2016). Barkema et al's research (2015) proved that people from the Middle East are not as concerned with the issue of unequal power distribution in contrast to employees in the West. Following the rules of democracy, Europe and the United States support equality in many significant areas; for example, power control, human rights, and social services (Ali 2005). In the Middle East, an authoritarian approach is widely used by governments and in business. This approach is based on the belief that employees following a high-power distance value are more respectful towards authority and management decisions. Thus, autonomy in employees' decision-making process is minimal (Barkema et al 2015).

Hofstede (author of the Hofstede 5-D model; 2015) devotes his research to the comparison between different cultures. One of his comparisons is devoted to the difficulties experienced in the relationship between the United States and Saudi Arabia (Hofstede 2015). The first dimension used in the study is the Power Distance Index (PDI), where Saudi Arabia scored 95. This high score means that Arab managers prefer to keep a hierarchy with no justification, and delegate tasks to subordinates. The United States scored 40 on this dimension, which means the presence of a hierarchy that requires positions to be justified. This score can be easily explained by the democratic values and liberties supported by the Western community (Hofstede 2015).

Following the cultural traditions of Individualism versus Collectivism (IDV), Saudi Arabia scored 25, compared to a score of 91 for the more independent United States. In democratic communities, loyalty is considered a crucial element and the core of social relationships. However, Western culture, including that of the United States, is known for individuals looking out for only themselves and their families, illustrating a significant difference in perceptions between the two cultures. The theory of individualism is widely apparent in the United States (Hofstede 2015).

As for the Masculinity versus Femininity (MAS) dimension, Saudi Arabia and the United States scored 60 and 21 respectively. A higher score for Saudi Arabia means that Middle Eastern managers are driven by business success that is defined by being the best in the field. A score of 62 for the United States in the masculinity dimension means that individualistic Americans strive for individual success (Hofstede 2015). In terms of Uncertainty Avoidance, Saudi Arabia rated 80 , meaning that their codes of behavior and beliefs cannot be applied to non-traditional behavior; the United States rated 46 on this dimension, meaning that their cultural principles are tolerant of different ideas (Hofstede 2015). With a score of 36 on Long-Term Orientation versus Short-Term Normative Orientation (LTO), Arab managers focus on short-term perspectives, with the same tendency being observed with managers from the United States, who scored 26 on LTO (Hofstede 2015).

Considering the results of Hofstede's (2015) research, it can be stated that expatriates can be valuable to an

Maurice Abi-Raad (2019), The Journal of Organizational Management Studies,

DOI: $10.5171 / 2019.730213$ 
organization only if they culturally adjust to the local norms and principles. Also, understanding nuances of high- and lowcontext cultures can help expatriates find a proper approach to people from different cultures (Hofstede 2015). Adjusting to a new culture can allow an individual to implement new ways of interacting with employees and colleagues from different backgrounds (Raţiu, Lazăr and Mortan 2011). The main cultural similarity found between the United States and Saudi Arabia is high competitiveness at different business levels (Schoknecht et al 2017). However, the other dimensions of Hofstede's (2015) research hold almost opposite positions, which explains why American expatriates struggle to adjust to Saudi Arabia's culture.

Hooker (2008), in his study "Cultural differences in business communication," gives good examples of the impact of culture on business communication. He explains the meaning of two types of communication used in the business sphere: high-context communication is based mainly on background information, while low-context communication delivers more details directly in the message (Hooker 2008).

The communication styles that people adopt in the West and the Middle East are considerably different. The Middle Eastern world relies more on silent contextual cues of high-context communication, in comparison to the Western world where people follow a low-context culture (Barkema et al 2015). Most of the conflicts and challenges are centered on different styles of cultural communication. Various cultural backgrounds may lead to communication problems, which can impact the safety of the entire region (Jalal 2017).

The difference between low- and highcontext communications can be observed in the area of business contracts. Western companies' contracts may take up to five pages of written text for a simple bicycle hire, while Middle Eastern companies, relying on information already known, provide only major elements in the contract. Middle Eastern managers may prepare written contracts to please Western business partners; however, the reality of the contractual terms may slightly change days after the document is signed (Hooker 2008).

Courtesy is considered an integral part of business relations in the Middle East. Arabic, Turkish, and some other Middle Eastern languages and dialects have many forms of polite speech. Thus, speech should convey a message that is understandable to anyone, enabling further productive discussions (Hooker 2008). The core of cross-cultural business is following one's business partners' thoughts enough to make efficient cultural adjustments. Managers in Western enterprises treat business as a self-contained activity, although it is a continual process based on pre-existing cultural mechanisms. If business depends on these dynamics there ought to be mutual appreciation for the cultural principles of both parties (Hooker 2008).

Power distance can also play a decisive role in the business communication process. The effects can be observed in verbal and non-verbal communication. Conflicts based on misunderstandings of body language are probably the most common (Hooker 2008). For instance, direct eye contact is considered as a sign of honesty in the Western world, while its meaning in the Middle East is closer to threatening. Also, crossing one's legs can be completely innocent in the West but possibly offensive in the Middle East. In Turkey, employees must keep their coat jackets buttoned if they are in the same room with their manager (Hooker 2008).

Kabasakal and Bodur (2002) highlight the general characteristics of the Arabic cluster and its difference with the Western world in their Journal of World Business article. GLOBE's (Global Leadership \& Organizational Behavior Effectiveness) Arabic cluster, namely; Qatar, Morocco, Turkey, Egypt, and Kuwait, is analyzed based on data collected by middle managers from local companies. The data describe the values and practices that are 
dominant in the given societies, as well as leader attributes. The data are analyzed using nine cultural dimensions. The sociallevel scores are applied to determine the cluster score by taking the average of five societal means (Kabasakal and Bodur 2002).

The results of GLOBES' Middle East study define family as the core of societal and individual relationships in Arabic cultures (Najm 2015). There is immense trust in family members in Turkey and Arabicspeaking countries of the cluster. The high significance of the family is explained by a hierarchy of relationships (Kabasakal and Bodur 2002). Arab culture teaches children to respect elders and authority figures (Mazahreh et al 2016). Thus, the norms and values taught in the family are applied to other social and governmental institutions. The relationships between the family and power distance can be widely observed in the Middle East, especially the Arabian Peninsula, where the government involves members of the ruling family (Kabasakal and Bodur 2002).

\section{Expatriates in the Middle East}

International enterprises entering the Middle East market need to demonstrate high competence in maintaining businesses that can adjust to the local environment (Thompson 2016; Dalal 2013). Similarly, local Middle Eastern enterprises need to promote practices and values that are acceptable in the Western world in order to remain competitive in the global environment. Thus, a dual set of values and principles that combines Western and Eastern characteristics has recently been observed in the Arabic cluster (Kabasakal and Bodur 2002).

Ourfali (2015) explores American expatriates' struggles in the Middle East. The research is based on individual, cultural, and organizational characteristics. Thus, the author highlights the different work orientations and satisfaction expressed by American expatriates and managers in the Middle East (Ourfali 2015). Generally, Arabs tend to be more collectivist due to their Islamic traditions, reflected in their higher respect for family members, colleagues, and business partners (Al-Wugayan and Rao, 2004). However, people in the Arab Gulf area are afraid of the possible effects expatriates may have on their local culture and identity (Ourfali 2015).

Arabic cultural traditions strongly reflect locals' behavioral habits. Arabian managers working in other countries with different cultures still follow essential Arabic cultural principles (Ourfali 2015), Arab culture demonstrates consultative and participative tendencies. Even though an autocratic management style is maintained by some managers, it does not create a conflict between business communities and political leaders (Ourfali 2015). Furthermore, Arabs emphasize consultation and are inclined to display humility while conducting business. This was evident through problems faced by non-Arab expatriates when socializing in the Middle East (different values, customs, language, and religion). At the same time, the Western business environment (in this case American) is based on flexibility and adjustability theory when adapting to a new working environment (Ourfali 2015).

Ali and Azim (1996), in their article "A cross-national perspective on managerial problems in a non-Western country," compare British and Indian managers working in United Arab Emirates (UAE)based companies. The results of their investigation reveal that American expatriates expect some responsibility for the decisions that have been made, which is rarely observed in the Arab work environment. Even though American expatriates are offered high pay rates compared to other expatriates, they still struggle to adjust to the authoritarian style widely practiced in the Middle East. Expatriates coming from less-developed, non-Muslim, and non-Arabic countries are less rewarded. Furthermore, Ali (2005) states that expatriates have problems managing Arab managers' weak knowledge of theory and research, as well as their lack of punctuality. This leads to limited social interaction, causing homesickness and 
social isolation for some expatriates (Ali 2005).

\section{Leadership in the Middle East}

In today's Middle East, the business sector is highly dependent on international enterprises bringing multi-million-dollar investments to local economies (Musibah, Shahzad and Bt Fadzil 2015; Odell 2017). Thus, this rapidly developing economy requires immense human resources to cover available job vacancies. For instance, the UAE has to engage a foreign workforce to meet the needs of the growing business sector. The problem lies in the foreign language and literacy barriers of the incoming workforce. Such issues add more work for managers, forcing them to adapt their management style to the new working arrangements (Jalal 2017).

If a Western company that has some of its facilities in the UAE is currently negotiating with local companies to engage more labor, the UAE business style should dominate. Business activity is not just about recruiting workers and managing their workload; it requires continuing current activities, providing materials, managing employees, and keeping working relationships harmonious. To achieve this, the entire spectrum of business activities needs to be accomplished in accordance with the norms and policies of the local culture (Hooker 2008).

The evolution of leadership in Middle Eastbased organizations was caused by economic changes after governments in the region implemented diversification strategies. The initial leadership style was authoritarian, due to a centralized form of management (Alnasseri, Osborne and Steel 2013).

Along with international companies entering local markets, pro-Western leadership styles are believed to be gaining popularity in the region. The consultative leadership theory is closer to the Western traditions but still aims to reflect Islamic values and principles (Alnasseri, Osborne and Steel 2013). Employers in the Middle East who follow this management style are more tolerant of employees' thoughts and ideas, although they still retain the right to make final decisions on their own (Alnasseri, Osborne and Steel 2013).

Preference and perception leadership styles (McCullough, MacLachlan and Moinpour 1982) are yet to find support, but some international companies are beginning to adopt these styles depending on the conditions (Nickerson and Goby 2017). Often, management of international companies with multi-cultural teams adopts a mix of democratic and authoritarian leadership styles. The diversity of the workforce requires more flexibility and tolerance from management (Alnasseri, Osborne and Steel 2013).

Kabasakal and Bodur's (2002) research explains the appreciation of leadership positions in Islam. The religion expects that people should not be critical of decisions made by their managers, as they are the main and the only authority in the company. Consequently, Islam supports class differences that have existed in Arabic countries for many decades (Kabasakal and Bodur 2002).

At the same time, the business sector in the Middle East region has started to apply some Western behaviors in businessrelated affairs (Al-shabbani 2015). For instance, a leader needs to create team spirit, enhance team commitment, encourage good performance, as well as meet company targets. Thus, a good leader in any state of the Arabic cluster can become closer to being a good leader in the Western world, but also have the main orientation found in collectivist cultures (Kabasakal and Bodur 2002). Participative leadership is also starting to have some influence on efficient leadership in the region (Baxter and Al A'ali 2016). This type of leadership stands far from nonautocratic and non-dictatorial manners, which are perceived to be the dominating values of Middle Eastern management. Humane leadership is a growing alternative to existing trends; humane leaders are more generous and compassionate (Kabasakal and Bodur 2002). 
The analysis conducted by Aycan (2001) demonstrates that a leader has the right to evaluate subordinates. This paternalistic type of leadership, where a manager is considered a "father" to subordinates, is highly supported in Turkey (Aycan 2001). Father leaders take all the responsibility for their subordinates, while the subordinates should obey their leader and demonstrate total respect for them. This leadership style makes it difficult to ensure career decisions correspond to objective career plans and performance evaluation methods (Aycan 2001).

\section{Honor, duty, and Rewards}

Hospitality is considered the core element of the Arab culture, bound up with honor and respect of your family, friends, colleagues, and business partners. People in the Middle East have developed an "honor culture" in which a person's worth is the core of their reputation, while their reputation is the core of what they do and what others think of what they do (Aslani et al 2013). This theory demonstrates the direction which negotiations between Western and Middle Eastern management will take. The core idea of an "honor theory" is self-worth (Aslani et al 2016). The Western world prefers the term "dignity theory," because self-worth is a reflection of social status, which is gained independently from social interactions (Aslani et al 2013). The Middle Eastern states, on the other hand, use the term "honor culture," because self-worth is a reflection of social status attained through social interactions (Aslani et al 2016). People strive to protect themselves and their families by competing for primacy and by developing a reputation for hospitality (Aslani et al 2013).

A sense of self-worth influences the process of negotiating new business relationships. There is, however, some argument among researchers over this point; Middle Easterners usually approach negotiations as a competition to maintain honor and respect in comparison to Westerners; who are inclined to measure honor by the outcome and more likely to approach a negotiation as a problem that needs a proper solution (Aslani et al 2013).

To find a logical grounding for these perceptions, Aslani et al (2013) introduced a simulation in which participants (Qataris and Americans) took the role of business owners aiming to expand their respective businesses. The main task was to develop a policy, including terms of employment, working conditions, and the recruitment of a family member to develop a joint website (Aslani et al 2013). They found that there were substantial differences in how American and Middle Eastern negotiators applied their strategy. Qataris turned out to be more competitive in their duty in comparison to the Americans; who set more aspirations in the preparation process (Aslani et al 2013). The Americans tended to be more open to exchanging information with each other, revealing all the details of their message. Qataris, however, shared considerably less information (Aslani et al 2013). Thus, application of a Western management style can be quite difficult in a Middle Eastern context due to differing levels of trust in negotiations in dignity versus honor cultures. This notion is known as "swift trust" in Western culture; where people trust each other after the first interaction, unless one of the parties has been proven to be untrustworthy (Aslani et al 2013).

Furthermore, citizens of the Middle Eastern states are less expressive when it comes to negative emotions, such as anger or frustration (Terris and Inoue-Terris 2002). Consequently, Al-Toubi, Al-Keyoumi, and Bachkirov (2015) highlighted the difficulties Western experts face when dealing with these emotional states, especially in the process of negotiations. It may be useful for American managers who are planning to get involved in new business relationships in the Middle East to remember that their potential partners accept the negotiation as a contest. This contest will most likely be won by means of emotional tactics, rather than information sharing (Aslani et al 2013). Thus, despite strong hospitable values, Middle Easterners become quite assertive in competitive situations (Aslani et al 2013). 
The same attitude is applied to how major duties are performed in the business sector. Western managers are more tolerant to learn from work-related errors and more eager to reward excellent performance (Koumpis 2013). In the Middle East, the level of tolerance regarding possible errors is considerably low, while any kind of personal achievement is considered a part of the collective work. Consequently, Middle Eastern managers do not apply one common system of employee rewards (Zgheib 2017).

\section{Localization (Arabization) of glossary and theories}

The process of Arabization was originally started in North Africa and then moved to the Middle East (Jaber 2015). All the states in the region adopted Islam as their main religion, but many of them also kept their language (Strengholt 2002). Over the past several decades, international investors who speak non-Arabic languages have had to adapt to the language realities of the region. To protect and revive Arabic languages, the process of Arabization was launched by governments in the Middle East (Ghazala 2013). For instance, the Kurds in Iraq fervently keep their language and cultural traditions alive, in comparison to government initiatives implemented by the Algerian and Iraqi authorities (Strengholt 2002).

Arabization is a simple process of transforming Modern Standard Arabic (MSA) to the level of a fully functional language in all sectors: education, business, and social affairs (Daoud 1991). Another definition characterizes Arabization as the lexical expansion that involves the coinage of new notions, both from existing words and translation of foreign notions (Faiza 2013). This is done to replace the language of the former European colonial powers.

Western experts might face difficulties while trying to adapt their policies to local conditions. The Weater theory of business adaptability to international standards also refers to language matters (Daoud 1991). All documentation is kept in Arabic, although English is the second most-used language in the region. Thus, the role of interpreters in international enterprises cannot be overstated in the Middle East. Even though a Western orientation is also evident in some intellectual circles, Arabization is still a major trend in the major states of the Middle East, especially those which are less open to foreign affairs (Daoud 1991).

In Morocco, Algeria, and Tunisia, Arabization is connected to government efforts to legitimize their regimes. At the same time, other independent states have also decided to remove colonial languages and adopt languages that would connect them with their Arabic roots. Since the 1980s, the process of Arabization has become an effective tool to counter radicalization (Strengholt 2002).

\section{Implementation Tolerance}

As a norm, international enterprises are unlikely to attempt to follow local management principles, preferring to adjust Western theories to the Middle East business environment (Reilly 2015; Managing Across Borders 2014). Western managers are challenged by the unwillingness of their non-Western colleagues to change their behavior, principles, and values according to business needs (De Waal and Frijns 2015). At the same time, Arab managers often express their frustration and confusion when they regard Western managers as inflexible, intolerant, or unwilling to adjust to local conditions (De Waal and Frijns 2015). This may lead to misunderstandings, which cause a lack of trust on both sides; cultural ambiguity, poor cooperation, and lost productivity.

Intercultural dialogue is at the core of business communication (Yun-Shiuan 2015). Western managers strive to show tolerance in the Middle East through appreciation of the individual's need for pragmatic adaption and an attempt to apply more permanent attitudinal or behavioral changes. de Waal and Frijns (2015), in their article "The influence of the UAE context on management practice in 
UAE business," describe the Western influence on the business environment using the example of the UAE. The article is based on research in which 42 managers, who represent an interesting cross-section of UAE organizations, were interviewed to gain an understanding of the business environment. The authors say that Dubai allows Muslims to develop Western-style consumerism while remaining true to their religion (de Waal and Frijns 2015). This "cultural hybridization theory," encouraged by Western experts, states that world cultures adopt a particular degree of homogenized global culture, but also retain aspects of their own traditions (De Waal and Frijns 2015).

The Middle East business environment is a receptive setting for adopting Western management techniques, considering the rapid economic development of the region. However, Western management techniques cannot be blindly transferred (duplicated) to non-Western contexts. At the same time, research on globalization detects that transferring management techniques from one region to another causes similar patterns of behavior across regions (De Waal and Frijns 2015).

The challenges faced by Western experts when implementing Western theories are based on numerous aspects, including: the religious aspect, workforce diversity, power centralization, conflict avoidance, and management style, etc. (De Waal and Frijns 2015). A transition from traditional business values toward a mix of Arab and Western business values makes it possible to implement Western management techniques successfully, when enterprises implementing these practices realize that a certain degree of tailoring is required to reflect the nature of, for example, the UAE business context (De Waal and Frijns 2015).

\section{Collective buy-ins}

Individualism/collectivism and power distance are regarded as the most significant values that cross the border between the East and the West (Wong, McKercher and Li 2016). Cultural values reflect humans' visions and perceptions of the surrounding world and other people (Barkema et al 2015). Individualism and collectivism measure the extent to which people appreciate individual and group interests and goals (Venkateswaran and Ojha 2017). For instance, the people of the Middle East are more collectivistic in comparison to those in the Western world. In addition, people in the Middle East have low trust in strangers initially, while Americans can easily engage in a conversation with strangers (Barkema et al 2015).

Western managers working in diverse enterprises with various numbers of Muslims, Christians, and Buddhists find that each group comes with their own values stemming from religious traditions (Weir 2001). Should Western values be enforced on them? The question is whether the individual values and the organizational values should be combined or not. The enterprise's management needs to agree on which values they are going to uphold-no matter from what state or region the employees are from (De Waal and Frijns 2015).

The difference in Middle Eastern and Western negotiation styles is based on the tribal business behavior in Middle Eastern culture (Asongu and Kodila-Tedika 2016). Most Arabic societies favor their tribal origins which are reflected in how they negotiate. Conversely, Western managers will first discuss the issues with the whole team before making a final decision and confirming an agreement. The Western business culture tends to conduct business processes fast and effectively (De Waal and Frijns 2015).

\section{Strong social network of connections}

The Arab management style is influenced by a long history of entrepreneurship which identifies certain norms in the decision-making process (Scott-Jackson and Michie 2017). Thus, Arab managers rely on their business instincts instead of hard data, and they also tend to focus on entrepreneurship, while recruiting others to carry out technical functions of the 
business (Anwar and Naim 2003). When it comes to business relationships and establishing social connections, Middle Eastern managers focus first on personal contact and less on tasks. Thus, the concept of a personal relationship with the other business party is of great importance to them for successful business performance. Moreover, Kabasakal and Dastmalchian (2001), in their work "Introduction to the special issue on leadership and culture in the Middle East," reveal that personal relationships are highly appreciated in the decision-making process, even more than the task itself. At the same time, Rice (2003), in her article "The challenge of creativity and culture: A framework for analysis with application to Arabian Gulf firms," explains that the challenge for Western managers is to focus on improving their relationship with non-Western managers; if they don't, their business affairs will not be effective.

Furthermore, the Arab practice of developing relationships before the actual business transaction takes place is perceived by the West to be very timeconsuming. Westerners believe that the style of developing business relationships is fast and effective, reducing unnecessary discussions and disputes. When relationships are established, written contracts are mandatory to confirm agreed obligations in both cultures (Anwar and Naim 2003).

In business negotiations, Western managers tend to be formal and focus on the objectives (Deresky 2014; Gholamreza, Davood and Ali 2011). Thus, they may be surprised to see Arab managers being argumentative and extroverted. Western experts mention that Arab managers prefer reaching consensus at the end of the negotiations, although the process itself might take longer than expected (Anwar and Naim 2003). Western managers tend to believe that negotiations should be short but efficient, while Arab executives would rather discuss issues unrelated to the business issue (Weir 2000). Apart from having flexible agendas, Western experts have difficulty in adapting to business meetings which are not exclusive to the meeting agenda. The negotiation process might simply fail when Arab managers notice that the negotiation changes from a bargaining to commanding style (Anwar and Naim 2003).

\section{Face-saving culture}

Middle Eastern countries all have a facesaving culture, avoiding shameful or embarrassing situations (Weir 1994; Foster 2002). Thus, Arab managers tend to "save face" when on their own or with people around them. Western experts admit the necessity to be careful when disagreeing with or contradicting a Middle Eastern manager in public (Foster 2002). Western business organizations face the challenge that Arab managers are poor at accepting criticism, as it causes them to lose face. At the same time, Arab managers are unlikely to disagree with Westerners, as they believe this would cause a loss of face for the Westerner (Foster 2002). Consequently, it may become hard to ascertain whether both parties can reach an agreement, or whether they are ready to proceed to the next stage of negotiations. Considering the Western approach in the context of the Middle East, it makes sense for Westerners to follow up a meeting via email or phone conversation to make it easier for Arabs to express their thoughts and ideas (Foster 2002).

Honor and duty are considered the basis of the Arab business culture (Sullivan and Ismael 1991). These principles are close to those of the Western culture, but the intensity of their direct implementation is considerably higher in the countries of the Middle East (De Waal and Frijns 2015). The concept is closely related to the sense of self-worth, especially in Arabic culture; in the honor culture of the Middle East, a person's self-worth is intrinsically derived and not conferred by others (Michalos 2017). Thus, face is maintained by having a reputation for respecting traditions and honoring elders (Kim and Cohen 2010).

In the Western world, relationship concerns are completely separate from other concerns in social and non-work settings. Thus, Arab culture is more likely 
to express negativity as a result of an intragroup conflict, while Western cultures keep tasks and personal relationship conflicts relatively separate. The same concept should apply to business relationships. For instance, in the Middle East, negotiations are influenced culturally as an important relationship issue (Sanchez-Burks et al 2008). For Westerners, this requirement to trust might be difficult; as they consider that others deserve to be trusted only when proven, the concept of "swift trust' is carefully considered. According to the study of "the Betrayal Aversion," described by Bohnet et al (2008), there are many countries where people need more information about a counterpart in order to trust them. The study explored the issue with an example of six countries, including Oman and Turkey from the Middle East region and the United States and Switzerland as representatives of Western culture. The results of the study revealed that Arabs expressed the highest level of betrayal aversion, which made them the least trusting among all nationalities (Bohnet et al 2008). As part of the facesaving culture, trust is considered to have significant implications in negotiations, where a lack of trust is associated with the distributive concepts and low joint gains (Sanchez-Burks et al 2008).

Generally, Arabian culture is considered a non-confrontational one which has lots of norms and restrictions. Consequently, it seeks the least amount of conflict possible. To overcome possible challenges while establishing businesses in the Middle East, Western experts suggest looking closely at all aspects of Arab culture (Ramdani et al 2014). Despite a so-called assertive temper, foreigners need to understand that Arabs avoid confrontation by resorting to a "face-saving" concept. This tactic allows them to get out of unpleasant situations without being embarrassed. To ensure success in business, Westerners need to learn and respect this cultural behavior in the region. This concept is relevant not only in the business sphere, but should also be followed in social and family relationships.
Saving face in the Arabic culture involves certain maneuvers for masking one's reactions, which can be difficult for Westerners to understand (Deresky 2014; Gholamreza, Davood and Ali 2011). The face-saving maneuver allows a person to exit a conflict the "right way," with minimal discomfort or harm to honor. Basically, the "saving-face" concept teaches the right behavior of high-quality ethics and manners. For instance, in the situation when someone tries to involve an Arabian manager in a position that is against their interest or beyond their capabilities, the Arabian might first assess the circumstances and then agree to make a deal (Parboteeah and Cullen 2017). The Western expert might interpret this action as an indirect "yes" answer. Thus, aggressive sales tactics or intense business negotiations may cause a misunderstanding among Arabian and Western managers by causing discomfort and inconvenience (Parboteeah and Cullen 2017).

\section{Moving forward: finding a workable solution to conducting business in the Middle East}

Today, many Western experts, managers, and investors have to deal with the foundations and fundamental principles of Middle Eastern culture while trying to enter the local business environment. Considering the close connection of Middle Eastern countries to Islamic traditions, the international "intruders" face a number of challenges regarding the social, economic, political, and business spheres (Donboli and Kashefi 2005). The countries of the Arab region also have to deal pragmatically with issues outside, or opposed to, Islamic legal principles. Being relatively dependable is an attempt by the Arab states to encourage foreign investments as the part of their diversification strategies (Donboli and Kashefi 2005).

The analysis conducted in this literature review has identified the possible challenges Western practitioners face when conducting business in the Middle East. These challenges include: the highand low-context cultures; honor, duty, and

Maurice Abi-Raad (2019), The Journal of Organizational Management Studies, DOI: $10.5171 / 2019.730213$ 
rewards; Arabization of terminology and theories; implementation tolerance; collective buy-ins; social network of connections; and face-saving culture.

Western experts face the challenge of adapting their low-context cultural habits to the Middle East's high-context culture, which is an important vehicle for conducting business. Honor, duty, and rewards are perceived as crucial components of business relationships both in the Western and Middle Eastern worlds. The main difference occurs in the kind of rewards implemented within the different cultures, and the type of relationships between employers and employees. Arabization is one of the key challenges for foreign managers, who will have to deal with documentation in the Arabic language. Thus, the importance of interpreters for international companies cannot be overstated. Western managers have to face non-Western colleagues' unwillingness to change their behavior, principles, and values according to business needs. Furthermore, Arab management do not welcome the perceived inflexibility and intolerance of Western partners who are unwilling to, or cannot, adjust to local conditions; this is the part of the facesaving culture that creates guidelines for proper behavior in Middle Eastern business relations.

\section{Proposed Interview Questions}

This paper represents the first step in this research, presenting an initial snapshot of the topic based on a literature review.

The next step involves conducting a series of interviews with organizational leaders who have presided over the introduction of Western theories in the field and have practical experience dealing with the issues and challenges involved.

The following are the proposed interview questions:

1. In your experience, what difficulties do Middle Eastern investors face while implementing
Western expertise in their respective business sector?

2. In your opinion, what implications may occur while conducting a direct style of communication in business negotiations within the Middle Eastern context?

3. Do the local cultural traditions cause additional challenges for the implementation of Western business theories in the Middle East? Please elaborate.

4. How would you describe the flexibility and adaptability level of the Middle Eastern business environment?

5. From your experience, what leadership style do you believe is the most dominant in the Middle East region and is it compatible with the leadership style followed by Western organizations?

6. What are the implications caused by the Middle Eastern leadership style when interacting with Western experts?

7. How would you best describe the compatibility of the Middle Eastern honor and duty concepts with Western theories?

8. In your opinion, what are the implications caused by localization/Arabization of Western theories of management and organizational practices?

9. In your opinion, how can cultural hybridization theory (adopting a particular degree of homogenized global culture, but also retaining aspects of their own traditions) be implemented in a Middle Eastern context?

10. Can Middle Eastern collectivism (the extent to which people appreciate individual and group interests and goals) be reflected in adapted Western practices?

11. What implications may occur while integrating the face-saving cultural components into Western organizational and management theories? 


\section{Conclusion}

The main objective of this paper, as mentioned earlier, is to examine the applicability of Western organizational and management theories in the Middle Eastern region and highlight the potential opportunities and barriers that could arise due to cultural differences between the two regions by reviewing the issues associated with: high- and low-context cultures; honor, duty, and rewards; localization (Arabization) of glossaries and theories; implementation tolerance; collective buyins; the social network of connections; and face-saving culture. It concluded by proposing an interview instrument that will be used to gather the opinions of experienced Middle Eastern organizational leaders working with Western experts.

\section{References}

1. Ali, A. J. (2005), Islamic Perspectives on Management and Organization, Edward Elgar Publishing Limited, Cheltenham, 139.

2. Ali, A.J., and A. Azim (1996) 'A CrossNational Perspective on Managerial Problems in a Non-Western Country', The Journal of Social Psychology, 136:2, 165172 ,

DOI:

$10.1080 / 00224545.1996 .9713990$

3. Alnasseri, N., Osborne, A., and Steel, G. (2013), 'Organizational culture, leadership style and effectiveness: a case study of Middle Eastern construction clients.' Paper presented at the Ahiaga-Dagbui, DD (Ed.), Proceedings of the 29th Annual ARCOM Conference.

4. Al-shabbani, Zamaan. (2015), 'The applicability of Western management in the middle east.' Theses and Dissertations - Civil Engineering. 32. https://uknowledge.uky.edu/ce_etds/32

5. Al-Toubi, I. M., Al-Keyoumi, Q.A. and Bachkirov, A.A. (2015), 'Building blocks of negotiation power: A study of top and middle managers in Oman,' Advances in
Business-Related Scientific Research Journal, 6 (2), 101-109.

6. Al-Wugayan, A.A. and Rao, C.P. (2004), 'An empirical investigation of consumer ethics in a collectivist Arab culture: customer-retailer relationship (CRR) approach,' Journal of International Consumer Marketing, 16 (3), 25-54.

7. Anwar, S.A. and Naim, C.M. (2003), 'Globalization of corporate America and its implications for management styles in an Arabian cultural context,' International Journal of Management, 20 (1), 43-56.

8. Aslani, S., Ramirez-Marin, J., Brett, J., Yao, J., Semnani-Azad, Z., Zhang, Z.-X., Tinsley, C., Weingart, L. and Adair, W. (2016), 'Dignity, face, and honor cultures: A study of negotiation strategy and outcomes in three cultures,' Journal of Organizational Behavior, 37, 1178-1201.

9. Aslani, S., Brett, J.M., Ramirez-Marin, J.Y. Tinsley, C.H. and Weingart, L.R. (2013), 'Doing Business in the Middle East,' [Online], [Retrieved October 27, 2017] https://insight.kellogg.northwestern.edu/ article/doing_business_in_the_middle_east

10. Asongu, S.A. and Kodila-Tedika, 0. (2016), 'Tribalism and government effectiveness,' Economics Bulletin, 37 (1), 156-167. African Governance and Development Institute WP/16/052.

11. Aycan, Z. (2001), Human Resource Management in Turkey, Koc University, Istanbul, 252-259.

12. Barkema, H.G., Chen, X., George, G., Luo, Y. and Tsui, A. (2015), 'West meets east: New concepts and theories,' Academy of Management Journal, 58 (2), 460-479.

13. Baxter J., Al A'ali H. (2016) Women leaders in the Middle East and the West, Speaking as Women Leaders, Palgrave Pivot, London. ISBN 978-1-137-50621-4

14. Bohnet, I., Greig, F., Herrmann, B. and Zeckhauser, R. (2008), 'Betrayal aversion: Evidence from Brazil, China,

Maurice Abi-Raad (2019), The Journal of Organizational Management Studies, DOI: $10.5171 / 2019.730213$ 
Oman, Switzerland, Turkey, and the United States,' American Economic Review, 98 (1), 294-310.

15. Dalal, Z. (2013), 'Taking your brand to the Middle East,' Franchising World, 45 (6), 56-57.

16. Daoud, M. (1991), 'Arabization in Tunisia: The tug of war,' Issues in Applied Linguistics, 2 (1).

17. De Waal, A. and Frijns, M. (2015), 'The influence of the UAE context on management practice in UAE business,' International Journal of Islamic and Middle Eastern Finance and Management, 9 (2), 236-253.

18. Deresky, H. (2014), International Management: Managing Across Borders and Cultures (8th ed.), Pearson Education Limited, Harlow, England.

19. Donboli, J.H. and Kashefi, F. (2005), 'Doing business in the Middle East: A primer for U.S. companies,' Cornell International Law Journal, 38 (5).

20. Faiza, D. (2013), 'Arabization planning: Algeria as an instance,' IOSR Journal of Humanities and Social Science, 18 (4), 25-28.

21. Foster, D. (2002), The Global Etiquette Guide to Africa and the Middle East, John Wiley \& Sons Inc., New York.

22. Ghazala, H.S. (2013), 'Arabization revisited in the Third Millennium,' Arab World English Journal, Special Issue (4), 25 .

23. Gholamreza, T., Davood, S. and Ali, T. (2011), 'Survey of leadership styles in different culture,' Iranian Journal of Management Studies, 3 (3), 91-111.

24. Goyal, Rishi. (2003), 'Non-oil growth, competitiveness, and the labor market,' in United Arab Emirates: Selected Issues and Statistical Appendix, IMF Country Report No. 03/67, Washington: International Monetary Fund, 41-58.
25. Hofstede, G. (2015), 'The 6 dimensions of national culture' National Culture, The Hofstede Centre [Online], [Retrieved November 11, 2017] http://geert-hofstede.com/nationalculture.html

26. Hooker, J.N. (2008), Cultural Differences in Business Communication Handbook of Intercultural Discourse and Communication, Blackwell.

27. Jaber, F. (2015), 'The landscape of translation movement in the Arab world: From the 7th Century until the beginning of the 21st Century,' Arab World English Journal, 6 (4), 128.

28. Jalal, A. (2017), 'Impacts of organizational culture on leadership's decision making,' Journal of Advances in Management Sciences \& Information Systems, 3, 1-8.

29. Kabasakal, H. and Bodur, M. (2002), 'Arabic cluster: A bridge between East and West,' Journal of World Business, 37, 40-54.

30. Kabasakal, H. and Dastmalchian, A. (2001), 'Introduction to the special issue on leadership and culture in the Middle East,' Applied Psychology: An International Review, 50 (4), 479-488.

31. Khdour, N., Harris, M. and Saif, N. (2015), 'Toward better understanding for the so called "A Fourth Paradigm" in the Arab world: A multiple case study on the telecoms sector in Jordan,' Journal of Management Research, 7 (3), 14.

32. Kim, Y.-H. and Cohen, D. (2010), 'Information, perspective, and judgments about the self in face and dignity cultures,' Personality and Social Psychology Bulletin, 36 (4), 537-550.

33. Koumpis, A. (2013), 'Learning from mistakes results in increase of corporate value,' International Journal of Advanced Corporate Learning, 6 (3), 1620. 
34. Kovac, M. (2007), 'Kuwait to cut oil dependency,' ICIS Chemical Business, 2 (51), 16.

35. Mathebula, T. (2017), 'The relationship between the practice of transformational leadership and a highperformance culture,' Proceedings of the European Conference On Management, Leadership and Governance, 562-571.

36. Mazahreh, L.G. and Stoltz, K.B., Wolff, L.A. and Turnage-Butterbauh, I. (2016), 'Cultural Variables and Factor Analysis of BASIS-A Using a Jordanian Sample,' The Journal of Individual Psychology, 72 (1), 45-59.

37. McCullough, J., MacLachlan, D. and Moinpour, R. (1982), 'Impact of information on preference and perception,' Advances in Consumer Research, 9 (1), 402-405.

38. Michalos A.C. (2017), Ancient observations on business ethics: Middle East meets West, How Good Policies and Business Ethics Enhance Good Quality of Life, Springer, Cham.

39. Middle East Monitor: The Gulf. (2014), 24(11), 1-12, Fitch Solutions, https://store.fitchsolutions.com/middleeast-monitor-the-gulf.html.

40. Mone, I.S., Benga, O. and Opre, A. (2016), 'Cross cultural differences in socialization goals as a function of power distance, individualism-collectivism, and education,' Romanian Journal of Experimental Applied Psychology, 7330334.

41. Musibah, A.S., Shahzad, A. and Bt Fadzil, F.H. (2015), 'Analyzing the business and economic scenario of foreign direct investment in Yemen compared with that of selected countries in the Middle East and North Africa (MENA),' International Journal of Business \& Information, 10 (1), 125-151.

42. Najm A. Najm. (2015), 'Arab culture dimensions in the international and Arab models,' American Journal of
Business, Economics and Management, 3 (6), 423-431.

43. Nickerson C. and Goby V.P. (2017), Exploring leadership communication in the United Arab Emirates: Issues of culture and gender, Challenging Leadership Stereotypes through Discourse, Ilie C., Schnurr S. (eds), Springer, Singapore.

44. ODell, A. (2017), 'Emerging status is just the start - opinion,' Global Investor, 1.

45. Oil \& Gas Industry Profile: Middle East. (2014), Oil \& Gas Industry Profile: Middle East, 1-33. ITP Media Graoup.

46. Ourfali, E. (2015), 'Comparison between Western and Middle Eastern cultures: Research on why American expatriates struggle in the Middle East,' Otago Management Graduate Review, 13.

47. Parboteeah, P. and Cullen, J.B. (2017), International Business: Perspectives from Developed and Emerging Markets, Routledge.

48. Platt, G. (2012), 'Crafting a new future,' Global Finance, 46-47.

49. Raduški, D. (2016), 'Basic management functions in culture and arts organizations,' Management (1820-0222), (81), 59-66. doi:10.7595/management.fon.2016.0024

50. Ramdani, B., Mellahi, K., Guermat, C. and Kechad, R. (2014), 'The efficacy of high performance work practices in the Middle East: evidence from Algerian firms,' International Journal of Human Resource Management, 25 (2), 252-275.

51. Rațiu, P., Lazăr, I. and Mortan, M. (2011), 'Improving employees and organizational performances through the expatriate process: A cross-case analysis,' Managerial Challenges of the Contemporary Society, (2), 248-255.

Maurice Abi-Raad (2019), The Journal of Organizational Management Studies, DOI: $10.5171 / 2019.730213$ 
52. Reilly, P. (2015), 'Managing across borders and cultures,' Strategic HR Review, 14 (1/2), 36-41.

53. Rice, G. (2003), 'The challenge of creativity and culture: A framework for analysis with application to Arabian Gulf firms,' International Business Review, 12, 461-477.

54. Saigal, K. (2013), 'South Sudan: Government tries to break its dependency on oil,' Euromoney, 43 (529), 74.

55. Sanchez-Burks, J., Neuman, E.J., Ybarra, O., Kopelman, S., Park, H. and Goh, K. (2008), 'Folk wisdom about the effects of relationship conflict,' Negotiation and Conflict Management Research, 1 (1), 5376.

56. Schoknecht, A., Thaler, T., Fettke, P., Oberweis, A. and Laue, R. (2017), 'Similarity of business process models-a state-of-the-art analysis,' ACM Computing Surveys, 50 (4), 52:1-52:33.

57. Scott-Jackson, W. and Michie, J. (2017), Culture and business operations: How the Gulf Arab leadership style impacts a contingent human resource management, Business and Society in the Middle East, Azoury N. (eds), Palgrave Studies in Governance, Leadership and Responsibility. Palgrave Macmillan, Cham, 31-47.

58. Sullivan, E.L. and Ismael, J.S. (1991), The Contemporary Study of the Arab World, University of Alberta Press, Edmonton, Alta., Canada.

59. Strengholt, J.M. (2002), Arabization Policies in Morocco, Algeria and Tunisia, London. This article is based on Jos M. Strengholt, Gospel in the Air; 50 years of Christian Witness through radio in the Arab World (Zoetermeer, 2008). This is his PhD thesis for the Faculty of Theology of Utrecht University in The Netherlands

60. Terris, R. and Inoue-Terris, V. (2002), 'A case study of third world jurisprudence-Palestine: conflict resolution and customary law in a neopatrimonial society,' Berkeley Journal of International Law, 20 (2), 462.

61. Thompson, R. (2016), 'Adjusting to the region's new reality,' MEED Business Review, 3.

62. Venkateswaran, R.T. and Ojha, A.K. (2017), 'Strategic management research on emerging economies,' Critical Perspectives on International Business, 13 (3), 204-225.

63. Weir, D. and Hutchings, K. (2005), 'Cultural embeddedness and contextual constraints: Knowledge sharing in Chinese and Arab Cultures.' Wiley InterScience [online], 12 (2), 89-98.

64. Weir, D. (1994), 'Is there a basis for a specifically Arab approach to management development?' Paper presented at the Arab Management Conference, University of Bradford, July.

65. Weir, D. (2000), Management in the Arab world. Management in Emerging Countries: Regional Encyclopedia of Business and Management, Business Press/Thomson Learning, London.

66. Weir, D. (2001), 'Management in the Arab world: A fourth paradigm.' Paper presentedat the First European Academy of Management Conference (April), Barcelona, Spain.

67. Wong, I.A., McKercher, B. and Li, X. (2016), 'East meets West,' Journal of TravelResearch, 55 (5), 628-642.

68. Yun-Shiuan (VIOLA), C. (2015), 'From the post-colonial to the intercultural-are genuine intercultural dialogues feasible?' Psych sociological Issues in Human Resource Management, 3 (2), 95-105.

69. Zgheib, P.W. (2017), Entrepreneurship and Business Innovation in the Middle East, IGI Global, United States of America. 